\title{
Legal Reasoning and Coherence Theories: Dworkin's Rights Thesis, Retroactivity, and the Linear Order of Decisions
}

\author{
Kenneth J. Kress $\dagger$
}

Coherence and holistic theories of truth maintam that a proposition is true if it fits sufficiently well with other propositions held to be true. Philosophers developed coherence theories im an atteinpt to avoid inadequacies in foundationalist accounts of trutl and justification offered by traditional empiricists. The empiricist prograin to construct a theory of knowledge that explains all trutlis as inferences from general first principles and particular experiences has proven to be difficult. ${ }^{1}$ There are serious objections to all of the major atteinpts. ${ }^{2}$

Led by Professor W.V.O. Qume's powerful arguments, ${ }^{3}$ ' coherence and holistic theories of knowledge and justification predominate in current Anglo-American philosophical circles, and foundational empiricist theories are on the wane. ${ }^{4}$ Coherence theories are more easily clrarac-

$\dagger$ Third-year law student and doctoral student, Jurisprudence and Social Policy Program, Boalt Hall School of Law, University of California, Berkeley. B.A. 1978, University of California, Los Angeles; M.A. (Jurisprudence and Social Policy) 1983, University of California, Berkeley. An early version of this Article was presented on April 12, 1980 under the title The Right Answer but the Wrong Right at the Stanford-Berkeley Student Philosoplry Conference held at the University of California, Berkeley. I am grateful to the commentator on that occasion, Richard Galvin, for his comments. More recent versions were presented at Boalt Hall School of Law, University of California, Berkeley, in November 1983 and at the philosophy department of the University of Illinois, Urbana-Cliampaign in December 1983. I regret that I am unable to list all of the many persons in attendance at these presentations, and others, who have made thoughtful and helpful remarks on the subject of this Article. It is with pleasure that I explicitly thank Robert Cooter, Melvin Eisenberg, George Fletcher, David K. Lewis, Joseplr Raz, Philip Selznick, Stuart Sobel, Jack Tweedie, and Richard Wasserstroin for thoughtful remarks. For perceptive comments on several drafts, I am especially indebted to Michael S. Moore, Phillippe Nonet, Gerald Postema, and Jan Vetter. A special thanks is due to Jules Coleman, whose comments on the very first draft helped me to see the full impact of ripple effect retroactivity on Dworkin's right answer thesis.

1. See, e.g., R. Carnap, The Logical Structure of the World (2d ed. 1967); N. Goodman, The Structure of Appearance (3d rev. ed. 1977).

2. G. Harman, Thought (1973); M. Williams, Groundless Belief (rev. ed. 1977).

3. W.V.O. Quine, Two Dogmas of Empiricism, in From A LoGICAL POINT OF View 20 (2d rev. ed. 1980) [hereinafter cited as W.V.O. QuINE, Two Dogmas of Empiricism]; W.V.O. QUINE, On What There Is, in From A Logical PoINT of VIEW 1 (2d rev. ed. 1980); W.V.O. QUINE, WORD AND OBJECT (1960) [heremafter cited as W.V.O. QUINE, WORD AND OBJECT]

4. See, e.g., G. HARMAN, supra note 2; M. WillLAMS, supra note 2; Harman, The Inference to the Best Explanation, 74 PHil. Rev. 88 (1965). In this Article, I gloss over the distinctions 
terized by their denial that knowledge has the linear structure that foundationalist theories assert, than by a full-blown positive doctrine, as unfortunately happens all too often in philosophical disputes. A coinplete and convincing coherence epistemology has also proven elusive. There is agreenent that the relation of coherence anong propositions is more strict than logical consistency, yet less strict than logical entailment. But it is unclear where coherence hes between the extremes of consistency and entailment. ${ }^{5}$ Nevertheless, the force of the criticism of foundationahsm, together with the suggestive and illummating beginnings by coherence theorists, has caught the philosophical inagination. Coherence theories of knowledge, ${ }^{6}$ justification, ${ }^{7}$ perception, ${ }^{8}$ truth, ${ }^{9}$ and ethics, ${ }^{10}$ to naine a few, have been proposed or developed in recent years. Coherence theorists have been a powerful, and perhaps the predominant, force in modern philosophy.

Given this philosophical climate, and the significant role played in law and adjudication by the concepts of legal and factual knowledge, legal and factual justification, legal and factual truth, and ethical truth and justification, it would not be surprisnig if legal theorists and legal philosophers were to develop coherence theories. Indeed, since the notions of precedent and argument from analogy have been explained in ways that resemble, and in ways that can be characterized as, hohstic and coherence theories, we should expect and welcoine the development of imphicit and explicit coherence theories by legal scholars. ${ }^{11}$

We have not been disappointed. For exainple, Professor Dworkin has argued that judges do and should determine the right answer in hard cases by deciding whether the proposition advocated by the plaintiff or by the defendant provides a better fit or coheres better with the best theory of settled law. ${ }^{12}$ Professor Moore has also given a central

among foundationalist theories and the differences among theories of justification, knowledge, and truth.

5. For a recent attempt to develop the concept of coherence, see N. RESCHER, THE COHERENCE THEORY OF TRUTH (1973).

6. Harman, supra note 4.

7. See supra note 3.

8. Chisholm, On the Nature of Empirical Evidence, in Empirical Knowledae: Readings From Contemporary Sources 224 (R. Chisholm \& R. Swartz eds. 1973).

9. See generally 2 B. Blanshard, The Nature of Thought 212-331 (1939); N. Rescher, supra note 5; Daucr, In Defense of the Coherence Theory of Truth, 71 J. PHIL. 791 (1974).

10. J. RAWLS, A THEORY OF Justice 46-53 (1971); Rawls, Outline of a Decision Procedure for Ethics, 60 PHIL. Rev. 177 (1951); see also R. Dworkin, TAKING Rights SERIOUSLY 159-60 (rev. ed. 1978). But see id. at 353 (denying that the reflective equilibrium coherence theory provides a satisfactory account of private moral reasoning).

11. The importance of precedent and the related requirement of treating like cases alike suggest that coherence theories are especially appropriate in theorics of adjudication.

12. See R. DWorkin, supra note 10, at 283; see also id. at 44, 340-42, 360. See generally id. at 81-130; Dworkin, "Natural" Law Revisited, 34 U. FLA. L. REv. 165 (1982) [hereinafter cited as 
role to coherence in his theories of facts, morality, ${ }^{13}$ law, and legal reasoning. ${ }^{14}$

There is mucli to be said in favor of colrerence theories and about their particular appropriateness to theories of legal reasoning. Nevertheless, I shall argue that currently accepted, and arguably desirable and necessary, features of modern Anglo-American legal systems ${ }^{15}$ and straightforward aspects of coherence theories will sometimes result in decisions that appear morally arbitrary.

This Article has two related purposes. First, I develop an internal criticism of Dworkin's theory of law and adjudication. Many writers have criticized Dworkin's theory externally, by denying one or more of his premises. I grant Dworkin's premises and then argue that the theory does not fulfill its own aims. Second, I generalize the criticisms of Dworkin, and apply them to other theories of adjudication.

Part I describes Dworkin's motivation for rejectimg positivism and his detailed criticisms of it. Part II examines Dworkin's theory of legal reasoning and presents an argument I call the "ripple effect." That argument leads to the conclusion that Dworkin's criticism of Professor Hart's positivism applies as well to Dworkin's own theory, the rights thesis. Dworkin claims that the positivist doctrine of discretion is unacceptable because it requires judicial legislation that results in retroactive application of law. The ripple effect argument shows that Dworkin's rights thesis is itself subject to retroactivity. Retroactivity is a more serious defect for Dworkin than for Hart because of Dworkin's commitment to the enforcement of preexisting rights and his right answer thesis. Part III considers potential responses to the ripple effect argument. Part IV illustrates the generality of the ripple effect argument. The ripple effect will occur in any coherence theory witl a principle of conservation. In adjudication, precedent provides the conservative element. This Part also argues that conservative coherence theories and, more generally, the doctrine of precedent lead to a mor-

Dworkin, "Natural" Law]; Dworkin, No Right Answer?, 53 N.Y.U. L. Rev. 1, 28-29 (1978) [hereinafter cited as Dworkin, No Right Answer?].

13. Moore, Moral Reality, 1982 W1s. L. Rev. 1061, 1106-10.

14. M. Moore, Law, Language and Ethics (tent. ed. 1981) (unpublished casebook on file with the California Law Review); M. Moore, A Natural Law Theory of Interpretation (Feb. 25, 1984) (originally presented at the University of Southern California Interpretation Symposium, forthcoining in volume 58 of the Southern California Law Review). See generally Moore, The Semantics of Judging, 54 S. CAL. L. REv. 151 (1981).

15. The restriction to Anglo-American legal systems should not be takeu to imply that there are reasons for believing that the arguuneuts presented in the text do not apply to other legal systems. Rather, they express the fact that the attempt to apply them to other legal systems has not yet been undertakeu. Insofar as other legal systems embody the preconditions of the ripple effect argument presented below, see infra text accompanying notes 53-76, 112-24, these conclusions hold for other legal systems also. Hereafter, I will use the term "legal systein" to refer to Anglo-American and relevantly similar systems. 
ally troubling linear ordering problem: legal rights depend upon the temporal order $\mathrm{m}$ which cases are decided.

Positivism AND THE Rights Thesis

\section{A. Dworkin's Motivation for Rejecting Positivism}

Dworkin's dissatisfaction with Hart's positivism provides the setting for the development of his rights thesis. ${ }^{16}$ Dworkin's claim that legal positivism is false provides major support for his rights thesis. The shortcomings Dworkin finds in positivism inform his attempt to develop an alternative theory that successfully avoids those defects. Thus, one must understand Dworkin's criticism of positivism to evaluate his theory of law.

Dworkin selects as his target H.L.A. Hart's important version of legal positivism in The Concept of Law. ${ }^{17}$ Dworkin claims that positivism is committed to four central claims: ${ }^{18}$

(1) Model of Rules: A legal system is a set of rules.

(2) Rule of Recognition and the Separation of Law and Morals: Vahid legal rules are distmguished from spurious legal rules and from moral rules and etiquette by a master rnle, the rule of recognition. ${ }^{19}$ The rule of recognition sets out specific noncontentful criteria for legality. Dworkin calls these criteria tests of "pedigree or the nuanner in which they were adopted or developed."20

(3) Discretion: The set of vahd legal rules is all there is to "the law." If a case is not clearly covered by rules, whether due to vagueness, conflicting rules, or a gap, the case is not covered by "the law."

16. R. DwORKIN, supra note 10, at 81-130 (Dworkin's theory of adjudication); id. at 14-80 (criticism of positivism); H.L.A. HART, THE CONCEPT OF LAW (1961).

17. H.L.A. HART, supra note 16. Dworkin's criticism appears in R. DwoRKIN, supra note 10, at 14-80. Dworkin attacks Hart's positivism, as Dworkin understands it, but he intends his criticisin to apply generally to all positivist theories. Id. at 22 .

18. R. DworkIN, supra note 10, at 17. Dworkin's list has been reorganized and renumbercd to better suit present purposes.

19. The rule of recognition is discussed in H.L.A. HART, supra note 16, at 92-107, and in R. DwORKIN, supra note 10, at 20-21. Oversimplifying greatly, the United States Constitution can be considered a rule of recognition insofar as it ultimately determines the validity of any purported law within its jurisdiction.

20. R. DwORKIN, supra note 10, at 17 (emphasis omitted). "Pedigree" has been used in many different senses in recent jurisprudential writings. The test of "pedigree" has somctimes been conceived of as: (1) a historical test; (2) a formal test; (3) a noncontentful test; (4) a nonmoral or morally neutral test; (5) a noncontroversial or easy to determine test; (6) a siunple or noncomplicated test; or (7) a mechanical test. Dworkin generally uses the term "pedigree" to mean a historical or morally neutral test, and sometimes uses it to mean a noncontroversial test. However, it is likely that Hart at most needs a morally neutral notion of pedigree. 
The judge must exercise his discretion, creating new law and applying it retroactively to the case at hand.

(4) Legal Obligation: Citizens have obligations and duties only when their cases are covered by valid rules. In hard cases, judges exercise discretion because there is no preexisting right to enforce. ${ }^{21}$

Dworkin's objections to positivism are motivated by the need to provide a principled justification for the state's use of coercion and force in enforcing judgments. Dworkin's early critique of positivism, The Model of Rules I, opens with the claim that we have a fragile understanding of the notion of a legal obligation:

Even in clear cases (a bank robber or a wilful breach of contract), when we are confident that someone had a legal obligation and broke it, we are not able to give a satisfactory account of what that means, or why that entitles the state to punish or coerce him. We may feel confident that what we are doing is proper, but until we can identify the principles we are following we cannot be sure that they are sufficient, or whether we are applying them consistently. In less clear cases, when the issue of whether an obligation has been broken is for some reason controversial, the pitch of these nagging questions rises and our responsibility to find answers deepens. ${ }^{22}$

Dworkin's criticism of legal positivism is based on the claim that the retroactive applications of law resulting from the positivist doctrine of discretion make it difficult to justify the use of the state's coercive power. ${ }^{23}$ Dworkin argues that Hart's doctrine of judicial discretion entails that judges legislate in hard cases, thereby creating new rights and then applymg those rights retroactively to the case at hand. ${ }^{24}$ Dworkin asserts that if this account of adjudication in hard cases were correct, the use of the coercive mechanism of the state to enforce those judgments would be not only unjustified but unjust: "We all agree that it would be wrong to sacrifice the rights of an innocent man in the name of some new duty created after the event."25 Thus, Dworkin's criticism of legal positivism is grounded in the diffculty of justifying retroactive

21. The claim that judicial discretion is a consequence of other positivist positions-for example, the view that rules do not resolve all cases and the view that in hard cases there are no preexisting rights-and not an argument for those positions is first clearly suggested by Dworkin in his introduction to THE PhLLOSOPHY of LAW 6-7 (R. Dworkin ed. 1977) (explicitly stating that the positivist doctrine that controversial legal propositions cannot be true or false supports the doctrine of discretion and denying the reverse).

22. R. Dworkin, supra note 10 , at 15 .

23. Dworkin also bases his objection to the positivist doctrine of discretion on the ground that it violates the democratic principle of separation of powers. Id. at $30-31,84, \&$ passim. In addition, Dworkin claims that positivists cannot satisfactorily explain and justify the phenomenon of overruling. For further discussion of these points, see infra note 97.

24. R. Dworkin, supra note 10 , at $17,30-39$.

25. Id. at 85 (emphasis added). 
application of law. In discussing what he describes as the "ex post facto" application of judicial discretion, Dworkin admits that:

This may not shock many readers-the notion of judicial discretion has percolated through the legal community-but it does illustrate one of the most nettlesome of the puzzles that drive philosophers to worry about legal obligation. If taking property away in cases [not covered by rules] cannot be justified by appealing to an established obligation, another justification nust be found, and nothing satisfactory has yet been supplied. ${ }^{26}$

Dworkin's theory of adjudication, the rights thesis, is designed to avoid retroactive application of law. Dworkin names his theory so that it wears its major claim on its face: judicial decisions enforce preexisting (pohtical) rights. ${ }^{27}$ The rights thesis is able to avoid retroactivity because it asserts the controversial right answer thesis: there are always legally authoritative standards (for example, principles) that recoininend single right answers in hard cases. ${ }^{28}$ This claim allows Dworkin to deny the positivist doctrine of discretion that leads to the charge of retroactivity, which itself leads to the further charge that enforcing judicial decisions im hard cases has not been justificd. There is no need for, and no rooin for, the positivist doctrine of discretion in Dworkin's theory. Because Dworkin's theory does not require, or even allow, judicial discretion, it has been thought to avoid retroactive application of law.

\section{B. Principles as Authoritative}

In criticizing Hart, Dworkin atteinpts to estabhish four propositions that form the foundation of his theory of adjudication. First, rules are distinguishable froin primciples. ${ }^{29}$ Second, judges use principles (in addition to rules). ${ }^{30}$ Third, principles are part of the law. ${ }^{31}$ Fourth, the positivists' inaster rule, the rule of recognition, ${ }^{32}$ camrot validate primciples as law. ${ }^{33}$ For purposes of this Article we need not determine whether Dworkin establishes any of the above propositions. $^{34}$ Brief explanation of the distinction between rules and primci-

26. Id. at 30 (emphasis added).

27. $I d$. at 87 .

28. Id. at 81, 279-90; Dworkin, No Right Answer?, supra note 12. Dworkin admits that it is theoretically possible that a case could have no right answer. He beheves that in a "modern, developed, and complex" legal system, such occurrenccs "will be so rare as to be exotic." Id. at 30-31, 32; see also R. DworkIN, supra note 10, at 334.

29. R. DWORKIN, supra note 10, at 24-28.

30. Id. at 23-24.

31. Id. at 29-39.

32. See supra note 19.

33. R. DworkIN, supra note 10 , at $39-44$.

34. For discussion of these issues, see Coleman, Negative and Positive Positivism, $11 \mathrm{~J}$. LgGAL 
ples and the argument that principles are part of the law will enhance understanding of the ripple effect argument proposed in Part II.

Dworkin's criticism of positivism in The Model of Rules $I$ begins with the claim that positivism underestimates the resources available im the law to settle hard cases. ${ }^{35}$ Dworkin claims that positivism has neither the theory nor the analytical tools for deciding cases that are not covered by rules. What positivism misses is the role in adjudication of policy, principle and other standards. ${ }^{36}$ In his article Hard Cases, Dworkin eschews policy (and other standards) as a basis for judicial decisionmaking and narrows his criticism to the claim that positivism misses the role of principles alone. ${ }^{37}$ Thus, Dworkin's attack on Hart's positivism revolves around the claim that in addition to rules, law contams principles. ${ }^{38}$

According to Dworkin, principles function differently from rules in the arguments that lawyers make about legal rights and obligations, particularly in hard cases. ${ }^{39}$ Dworkin tells us that there is a logical distinction between legal rules and legal principles. Rules apply in an all-or-nothing fashion. ${ }^{40}$ They can be canonized as general statements of the form "whenever $A$, then $B$ " where " $A$ " states facts and " $B$ " states a legal conclusion. ${ }^{41}$ If the antecedent $A$ holds, $B$ must be accepted. If $A$ does not hold, $B$ does not follow and the rule contributes nothing to any legal argument. Rules may have exceptions, but the exceptions would be included in an accurate statement of the rule. ${ }^{42}$ In particular, rules cannot conflict. If two rules conflict, at least one of them is wrong, that is, not really a rule. As examples of rules, Dworkin gives us "A will is not valid unless signed by three witnesses" and "The

STuD. 139 (1982) [hereinafter cited as Coleman, Negative and Positive Positivism]; Coleman, Book Review, 66 CALIF. L. Rev. 885 (1978) (reviewing R. DWorkin, Taking Rights Seriously (1977)) [hereinafter citcd as Coleman, Book Review]; Lyons, Principles, Positivism, and Legal Theory (Book Review), 87 YAle L.J. 415 (1977) (reviewing R. Dworkin, TAKING Rights SERIousLY (1977)). Additional discussion of Dworkin's views can be found in RoNALD DWorkin and Contemporary JuRISprudence (M. Cohen ed. 1984); Symposium: Taking Dworkin Seriously, 5 SOC. THEORY \& PRAC. 267 (1980), and in Jurisprudence Symposium, 11 GA. L. REv. 969 (1977).

35. R. DwORKIN, supra note 10, at 22.

36. Id.

37. Id. at 81-130. Arguably, in his reply to Professor Greenawalt, Dworkin uses the concept of an argument of principle in so expansive a way that it includes what would ordinarily be thought of as policy arguments. Id. at 294-330.

38. Id. at 22.

39. Id.

40. Id. at 24 .

41. Actually, this claim needs refinement since there may be chains of legal inferences. For example, [if $A$, then $B$ ] and $A$, therefore $B$; but also [if $B$, then $C$ ], therefore $C$, and so on. Thus, $A, B$, and $C$ may be mixed statements of fact and law; or they may be statements of fact relative to oue rule yet statements of law relative to another.

42. R. DWORKIN, supra note 10 , at 25 . 
maximum speed on the turnpike is sixty miles per hour." 43

Principles, according to Dworkin, do not provide for legal consequences that follow whenever certain conditions are met. "For example, the legal principle that no man shall profit from his own wrong is not refuted by the doctrine of adverse possession or the fact that a man who jumps bail to make a brilliant investment in another state will keep his profits (although he may be returned to jail). ${ }^{44}$ Rather, Dworkin claims, principles have a dimension of weight or importance. ${ }^{45}$ Principles state reasons for a particular decision, but may not require it. For there may be principles of greater weight that point to the opposite conclusion.

That a particular principle does not determine a decision to which it applies does not, according to Dworkin, mean that it is not part of "the law":

[A] principle may not prevail but that does not mean that it is not a principle of our legal system, because in the next case, when these contravening considerations are absent or less weighty, the principle may be decisive. All that is meant, when we say that a particular principle is a principle of our law, is that the principle is one which officials must take into account, if it is relevant, as a consideration inclining in one direction or another. ${ }^{46}$

If principles are not part of the law, Dworkin argues, then we cannot escape the unjustified retroactivity that undermines positivism. Dworkin sets up an alleged dichotomy: ${ }^{47}$ either

(a) principles function authoritatively within the law the same way rules do in the sense that they are bimding as law. Thus, they must be taken into account by judges and lawyers who make decisions of legal obhgation: principles are part of "the law"; or

(b) principles cannot ${ }^{48}$ be bimding. They are not part of the law but are rather available to judges to use in hard cases if they so choose.

Dworkin claims this distmction is more than just a verbal question of the application of the word "law":

The choice between these two accounts has the greatest consequences for an analysis of legal obligation. . . . The choice between these ap-

43. Id. at 24 .

44. Id. at 25 .

45. Id. at 26 .

46. Id.

47. Id. at 29. The dichotomy is not jointly exhaustive. It may be the case that some principles judges cite are part of the law while others that they cite are not. See Raz, Legal Principles and the Limits of Law, 81 YALE L.J. 823, 836 (1972).

48. Dworkin erroneously employs the modal term "cannot." The appropriate parallel to (a) would be: (b) principles are not binding. 
proaches will affect, perhaps even determine, the answer we can give to the question whether the judge in a hard case . . . is attempting to enforce pre-existing legal rights and obligations. If we take the first tack [(a)], we are still free to argue that because such judges are applying binding legal standards they are enforcing legal rights and obligations. But if we take the second [(b)], we are out of court on that issue, and we must acknowledge that the [litigants in hard cases are] deprived of their property by an act of judicial discretion applied ex post facto. ${ }^{49}$

Thus, according to Dworkin, unless we acknowledge that principles are part of the law, we cannot avoid the unjustified enforcement of retroactively applied law. Where the positivist finds a gap in the law because rules do not provide guidance, Dworkin discovers preexisting legal rights supported by authoritative principles.

\section{II}

\section{Dworkin's Theory of Legal Reasoning AND THE RIPPLE EFFECT ARGUMENT}

Dworkin claims that the rights thesis avoids the unjustified retroactivity that besets positivisin. A close examination of Dworkin's theory of legal reasoning reveals that Dworkin's rights thesis is vulnerable to the same criticism Dworkin makes of Hart's positivism. The rights thesis requires retroactivity as well.

\section{A. The Settled Law and the Determination of Authoritative Principles}

To understand the ripple effect argument it is necessary to exphcate Dworkin's theory of legal reasoning. While the broad outlines of Dworkin's theory of law are clear, there remaims room for debate on many of the details ${ }^{50}$ and Dworkin's views will probably continue to evolve. ${ }^{51}$ Fortunately, the variations that occur in Dworkin's expression of his theory and the respects in which the account below may elaborate upon or differ from Dworkin's current views will not affect the conclusions of this Article. ${ }^{52}$

The rights thesis maintains that even in a hard case, where rules do not provide definitive guidance, there is a single preexisting right answer. Guidance is provided, according to Dworkin, by authoritative principles. The judge's problem is to determine which principles are

49. R. DworkIn, supra note 10, at 29-30 (emphasis added).

50. E.g., W. Wilcox, A Theory of Legal Theory 167 (August 1981) (unpublished doctoral dissertation on file with the California Law Review).

51. Dworkin's views have evolved in a number of articles published over the last twenty years. In soine respects, the later essays elaborate upon earher essays. In other respects, the later essays involve changes in doctrine. See Lyons, supra note 34, at 415; see also infra note 53.

52. For discussion of one respect in which iny account may diverge froin Dworkin's view, see infra text accompanying notes 109-11. 
authoritative. Dworkin's answer is that a principle is part of the law and hence authoritative if it is part of the theory that provides the best explanation and justification of the settled law.

According to Dworkin, ${ }^{53}$ when a judge confronts a legal question he should first determine the settled law in the jurisdiction. Settled law consists of the coinplete institutional history of the jurisdiction including constitution(s), enactinent and repeal of statutes, judicial pronouncements, and perhaps administrative rulings. To simplify somewhat, settled law is the explicit, clear, black letter law. ${ }^{54}$ Soine aspects of the settled law may be disregarded as mistakes. Dworkin's theory for determining whiclı prior decisions and other parts of mstitutional history may be considered mistakes is quite complicated. ${ }^{55}$ Those parts of institutional history that are no longer persuasive to courts, legislatures, and the legal profession are particularly vulnerable to being labeled mistakes. So too are those parts that are unjust. ${ }^{56}$ Adjusting the settled law by deleting mistakes is a subtle process that Dworkin has described as seeking a "reflective equilibrium" between the institutional facts and a coherent theoretical structure that could justify those

53. The account that follows is largely taken from Dworkin's maugural lecture as Professor of Jurisprudence at Oxford, Hard Cases. R. DwORKIN, supra note 10, at 81-130. In his reply to critics, Dworkin amends the theory, giving a tentative account of the tradeof between the dimension of fit (explanation of the settled law) and the dimension of moral appeal (justification of the settled law). Roughly put, the best theory of settled law is the most morally appealing theory of all those theories that exceed a set threshold of fit. Id. at 340-42, 360. In yet more recent writings, Dworkin suggests that the threshold of fit is not an absolute minimum, but only a rule of thumb. A theory that is sufficiently better on moral grounds than any theory that meets the threshold of fit may be the best theory of settled law even if it does not quite reach the threshold. See, e.g., Dworkin, "Natural" Law, supra note 12, at 171-72.

The greater emphasis that Dworkin's writings since Hard Cases place on substantive moral considerations and consequent lesser role played by the notion of fit suggests that the new theory may not be a strict coherence theory. Whether the new theory is a pure coherence theory will depend upon whether moral thcory, and the full theory that combimes or adjudicates between moral appeal and fit, are pure coherence theories.) In any event, the ripple effect argunent presented in Part II, suitably modified, will apply to any version of the new theory.

Additionally, this interpretation of Hard Cases may be inaccurate if Dworkin intends his theory of legal truth to parallel those aspects of Qume's theory of evidence that reject the analytic/ synthetic distinction in favor of a "contmuum" of propositions from those at the center of our field of beliefs to those at the periphery. See W.V.O. QuINE, Two Dogmas of Empiricism, supra note 3, at 42-46. But see R. Dworkin, supra note 10, at 164-65 (denying that Quine's theory is an accurate picture of the technique of refiective equilibrium that is analogous to common law adjudication and distinguishing the natural and constructive models of theorizing). However, the ripple effect argument that will be presented below applies, with the necessary changes, to a Quinean interpretation of Dworkin. For further discussion of this point, see infra text accompanying notes 110-11.

54. Dworkin's thcory is more complex because it attempts to explain and justify not only currently operative law but, in addition, the enactment and repeal of a statute and a judicial decision and its later overruling. See, e.g., R. Dworkin, supra note 10, at 342, 360; Dworkin, "Natural" Law, supra note 12, at 165, 166, passim.

55. R. DworkIN, supra note 10, at 1I8-23.

56. Id. at 122-23. 
facts. ${ }^{57}$ In the attempt to determine the best theory of the institutional facts, neither the judge's initial theory nor the judge's initial view of the settled law is immune from revision. Either may require revision in the attempt to obtain an equilibrium that best accommodates both. More likely, both will require revision. Put briefly, the judge should construct or determine that theory $S T L$ (the soundest theory of law) which best explains and justifies the settled law.

The soundest theory of law may be conceived as a set of basic principles $P$ from which each of the propositions of settled law $S L$ follow by deductive logic (or some shightly less strict form of theoretical consequence). ${ }^{58}$ However, there are some propositions of law $L$ which will remain open in the sense that neither the proposition nor its negation will follow deductively (or theoretically) from the basic principles $P$. The set of all such propositions $L$ comprises the set $N$ of nonconsequences. This set $N$ of nonconsequences can be conceived as a set of ordered pairs of propositions and their contradictories. Since on Dworkin's theory there is always a single right answer, exactly one member of each pair of contradictories will be true. The class consisting of all the true members of these ordered pairs is the set of true but unsettled law, UC. (Intuitively, these are the iniphicitly true legal propositions, the coherence consequences.) The truth of a member of $U C$ cannot consist in its following from $P$, the principles, by definition. Rather, Dworkin tells us, the meinbers of $U C$ are true by virtue of coherence. For example, if not- $L$, a member of the set $N$ of nonconsequences is more coherent with $S T L$ than $L$ is, not- $L$ is true (and thus a member of $U C$ ), whereas $L$ is false (and not a meinber of $U C$ ), and vice versa.

Thus, at any time, propositions of law that are not consequences of the basic principles $P$ are true (or false) by virtue of their greater (or lesser) coherence with the soundest theory of law at the time. On the other hand, from the perspective of the theory, propositions of settled law may be said to be true by virtue of their following logically (or theoretically) from the basic principles $P .{ }^{59}$

57. Id. at 155, 159-68. The term "reflective equilibrium" derives from Rawls, who employed the concept in connection with moral theory and the theory of justice. J. RAwLs, supra note 10, at 46-53; Rawls, supra note 10.

58. The theoretical consequences that are not logical consequences contemplated in the text include analytic consequences, by which I mean consequences flowing froin the meanings of words. Discussion and criticism of the concept of analyticity can be found in the writings of Quine. See sources cited supra note 3. The text leaves open the possibility that theoretical consequence also encoinpasses consequences even less strict than analytic but nnore strict than coherence. Nothing in this Article will depend upon the particulars of such inore expansive forms of theoretical consequence.

59. This assertion may be misleading. The qualification "from the perspective of the theory" is significant because it signals one respect in which the strict separation of legal truths into settled law and coherence consequences is misleading. See infra text accompanying notes 109-11. 
B. The Ripple Effect Argument:

The Right Answer but the Wrong Right

Dworkin's theory of legal reasoning is built on the proposition that litigants are entitled to the enforcement of preexisting legal rights. One way im which the rights thesis expresses this major claim is by presupposing that litigants liave a right to lave decisions in civil cases determined by settled law. ${ }^{60}$ In Dworkin's theory, settled law (together with moral theory) determines litigants' rights and litigants' rights determine the proper outcome. Thus, decisions are a function of, among other things, the settled law.

The argument I call the "ripple effect" relies upon these featurcs of the rights thesis. In particular, the ripple effect argument depends upon legal rights beimg a function of settled law and upon the temporal gap between events being litigated and their eventual adjudication. Judicial decisions change the settled law. Often, if not always, the settled law will be changed between the occurrence of events being litigated and their eventual adjudication. In consequence, a litigant's rights will sometimes also be changed. If changes im the settled law change the dispositive legal right, a litigant who would have prevailed given the legal rights existing at the time of the occurrence will lose because he no longer has that right at the time of adjudication. The opposite is true of the opposing litigant.

This is retroactive application of law. The ripple effect argument suggests that the rights thesis sometimes enforces the wrong preexisting right. The rights thesis does not enforce the right that the prevailing party had when the events being litigated occurred, but rather the possibly different right existing at the time of adjudication.

\section{The Ripple Effect Argument}

Dworkin's theory tells us that in a hard case, when a judge is called upon to decide a legal question $Q$ that is not a logical (or theoretical) consequence of the primciples $P$, he must do so by determining whether $Q$ or not- $Q$ coheres better with the soundest theory of law $S T L$. Consider a case where $Q$ coheres better with $S T L$ than not- $Q$ does and the judge so holds. By virtue of that judical decision $Q$ is no longer part of the true but unsettled law $U C$. It is now part of the settled law. This disturbs the theory $S T L$ and, as one would expect in a coherence theory, has ripple effects ${ }^{61}$ on the rest of the system. More

60. Coleman, Book Review, supra note 34 , at 904 .

61. The terminology "ripple effect" was chosen to reflect the common metaphors of a coherence theory as a unified field of propositions, or as a spider's web with propositions at the intersections of the web's strands. Because of the many interconnections among the propositions (or points), any change in the location of any proposition within the field or web will occasion ripple 
precisely, settled law now contains one more proposition, namely $Q$. Call the new settled law $S L^{\prime}$. The new soundest theory of law $S T L^{\prime}$ will, in general, differ from $S T L$ smce it must explaim and justify the additional data $Q .{ }^{62}$ While $S T L^{\prime}$ need not necessarily cohere with a different set of propositions than $S T L$, in most cases $S T L^{\prime}$ will so differ. With at most rare exceptions, $S T L^{\prime}$ will cohere with a different set of propositions than $S T L$ did. That is, for some proposition $X$ of the set of nonconsequences $N, X$ cohered better with $S T L$ than not- $X$ did, and was hence true and a member of $U C$ with respect to $S T L$ before the decision. After the decision, not- $X$ coheres better with $S T L^{\prime}$ and is hence true and a member of $U C^{\prime}$ with respect to $S T L^{\prime} . X$ was true but became false as a ripple effect of $Q$ being settled by exphicit judicial decision. Thus, while the judge discovered and did not create the truth of $Q$, the question at issue, he nonetheless created as an unintended consequence the truth of not- $X$. In a sense this should have been obvious: judicial decisions change the law.

Once it is admitted that judicial decisions can change the truth value of propositions of unsettled law by the ripple effect, it is easy to see how retroactive application of law can arise. Suppose that a lawsuit is pending in which $X$ is dispositive. In the above example, if $Q$ is settled after the events that gave rise to the lawsuit but before it comes to judgment, the law will change from $X$ to not- $X$ and a litigant will be subject to retroactive application of law. ${ }^{63}$

Note that the judge has inadvertently caused retroactive application of law, without exercismg discretion. $Q$ was the right answer, re-

effects on the rest of the propositions in the field or web. See, e.g., W.V.O. QUINE \& J. ULLIAN, THE WeB of BELIEF (2d ed. 1978); W.V.O. QUINE, Two Dogmas of Empiricism, supra note 3, at $42-44$.

62. Since $Q$ was part of the unsettled law, neither $Q$ nor not- $Q$ followed logically or theoretically froin $P$.

63. The arguinent is quite general. It requires only that legal truths soinetimes change when settled law is enlarged by new decisions and that sometimes such changes occur in legal propositions that are dispositive of cases where the events occurred prior to the change and the adjudication occurs after the change.

The generality of the argument can be seen even more clearly in hight of a set-theoretic characterization of coherence. Conceive of coherence as a matheinatical function from sets of accepted data (or truths) to sets consisting of all true propositions including those true by virtue of coherence with accepted data. In Dworkin's theory, for example, the coherence function will take as argument (or input) institutional histories (or settled law) and will produce as value (or output) the complete set of legal truths given that institutional history. All that is required for ripple effects is that sometimes different inputs result in different outputs from the coherence function $C$. Put set theoretically, all that is required is that the coherence function $C$ be nonconstant. In other words, a restriction of the image of $C$ is a function.

Given that minimal condition, ripple effects will occur. As noted above, retroactive application of law will occur if any such ripple effects change dispositive propositions of cases whose events occurred prior to the ripple effect and whose adjudication occurs after. For further discussion of the generality of this argument, see infra text accompanying notes 112-23. 
quired by Dworkin's theory of adjudication, since $Q$ cohered better with $S T L$ than not- $Q$ did. Thus, we see that Dworkin's rights thesis requires that, without exercising discretion, judges soinetimes retroactively apply law. Dworkin claims that the rights thesis is preferable to positivisu because by avoiding judicial discretion it avoids retroactive application of law. That claim goes awry because it equates judicial discretion with judicial creation of law. In fact, it is the creation of new law, and not judicial discretion, that leads to the possibility of retroactivity. Once the concepts of law creation and judicial discretion are distinguished, it is possible to see how, without exercising discretion, applying law created (perhaps by other judges) after the events being litigated occurred can result in retroactive application of law. The acts of "law creation" by prior judges that result in the current judge's nondiscretionary yet retroactive application of law were themselves performed without exercising judicial discretion, according to Dworkin's own theory. ${ }^{64}$

A simplified example will illustrate the basic thrust of the ripple effect argument. Consider a hypothetical jurisdiction which is just developing the law of privity of contract. Suppose that in this jurisdiction, a case lolds that direct contractual relations give rise to liability. For exainple, one may sue those from whoin one purchases defective merchandise; liability exists at one step removed. However, another case holds that there is no liability six steps down the line. If consumer $A$ buys from retailer $B$ who bought from local distributor $C$, who bought from regional distributor $D$... who bought from manufacturer $G, A$ may not recover from $G$ even if the product is defective. Assume for the sake of illustration what is undoubtedly false, that each step in the cham of privity is of equal moral and legal "distance" im the relevant respects. ${ }^{65}$

The geometric inodel of the doctrime of precedent tells one, im a hard case, to split the legally relevant distance between the closest cases

64. The conflation of judicial discretion and judicial creation of law may result from the connection between discretion and legislation. By equatimg judicial discretion with judicial legislation, and legislation with creation of law, one might conclude that discretion entails creation of new law. In fact, discretion neither entails nor is required for creation of new law. First, discretion may exist but not result in legislation or creation of new law. A legal system could allow that im some areas where law is clear, judges may nonetheless be accorded discretion to change that law. Whenever the judge "exercises" discretion to retain the old law, discretion without legislation or creation of new law occurs. Second, as the text demonstrates, new law may be created without judicial discretion.

65. I have deliberately chosen an example where it is wildly implausible to suppose that the steps in question are of equal morally or legally relevant distance in order to focus on the general poimt. A more plausible example would draw attention to the details of the example, and whether the example's steps were of equal distance, thereby losing sight of the general point. 
on point. ${ }^{66}$ If a novel privity case were to come up in our jurisdiction at this point in time, the judge should find liability if the plaintiff is two or three steps reinoved simce, by our assumption, two and three are closer to one than to six, and four and five are closer to six than to one. However, suppose that the next case decided is four steps relnoved and the judge correctly finds no liability. If a case three steps removed comes up at this point, the plaintiff will lose because three is closer to four, the closest no-liability case, than to one, the closest liability case. Although our imaginary plaintiff would have won had his case preceded the fourstep case, lie now loses. This situation creates a race to the courthouse that appears contrary to our notions of justice. If the three- and fourstep cases are going up the appellate ladder simultaneously, an unfortunate situation results. If the four-step case reaches the top first, the defendants in the three- and the four-step cases win; if the three-step case reaclies the top first, botli plaintiffs win.

Of course, this is only a fanciful example. It assumes that precedent or argument by analogy is the whole of legal reasoning, while in any sophisticated legal system it will only play a part. In Dworkin's sclieme, argument by analogy, colierence, or institutional fit (that the soundest theory of law must explam the settled law) coinpetes with moral appeal (that the soundest theory of law must justify the settled law) in the account of legal reasoning. ${ }^{67}$ Nonetlieless, to the extent that precedent plays a part, the ripple effect will occur, bringing in its wake retroactive applications of law. ${ }^{68}$ Precedent indeed plays a substantial role in Dworkin's theory. He tells us that the principle of fairness that like cases be treated alike requires that prior decisions lave "gravitational force." 69

\section{The Right Answer but the Wrong Right}

The ripple effect arguinent suggests that the right answer thesis is incorrect because it requires enforcement of the wrong right. As

66. The geometric model of precedent as splitting the legally relevant distance between the two closest cases, or lines of cases, on point is a paradigm example of a step-by-step coherence theory with a principle of conservation that leads to ripple effects. For a classic characterization of the geometric model, see E. LEVI, AN INTRODUCTION TO LEGAL REASONING 5 n.8 (1949). Dean Levi does not appear to endorse this geometric model.

67. R. DwORKIN, supra note 10 , at $40-45,60-65,81-130,342-44,360$.

68. Additionally, it must be admitted that theories of precedent that do not "split" the legally relevant distance are both possible and plausible. Such theories may maimtain that when a new case "between" the two cases closest on point is decided, the borderline between plaintiffs' cases and defendants' cases does not move to half the distance between the new decision and the closest contrary case. Rather, these theories claim that precedent will result in the borderline moving a lesser amount in the direction of the closest contrary case. Such theories of precedent will allow fewer instances of ripple effect retroactivity, but will not totally avoid them.

69. R. DwORKIN, supra note 10, at 110-18. 
Dworkin develops his theory in Taking Rights Seriously, it appears that judges are to enforce the rights that exist at the time of adjudication (adjudication rights). ${ }^{70}$ The ripple effect argument establislies that the rights existing at the time of the event in issue (event rights) may differ from the adjudication rights. Unless event rights are enforced, the point of enforcing preexistimg rights will be lost because law will be applied retroactively. ${ }^{71}$

Nowhere in Dworkin's writings does he explicitly discuss the question whether the right answer thesis applies to event rights or adjudication rights. The issue does not appear to have occurred to him. However, Dworkin's insistence on the injustice of "sacrific[ing] the rights of an innocent man in the naine of some new duty created after the event"72 is substantial evidence that he may believe tliat judges should enforce the rights existing at the time of the events. Tliere are also strong arguments from the requirements of the rule of law that citizens be given notice of the laws to which they are subject and that their justified expectations not be upset, particularly when they liave rehed upon those expectations. ${ }^{73}$ The arguinents froin the rule of law

70. R. DwORKIN, supra note 10, at 81-130.

71. See infra note 73 and accompanying text.

72. R. DWORKIN, supra note 10 , at 85 (emphasis added).

73. Dworkin beheves that the unfairness of retroactive application of law is not fully explained by the rule of law requirements to give prior notice, satisfy justificd cxpectations, and the like. Id. at 335-38; see also id. at 85-86, 325 . Dworkin must take this position because the controversial nature of right answers even when they exist means, as Dworkin admits, that right answers often cannot be demonstrated and therefore often are not known in advance. Id. at 81 . Dworkin's objection to retroactivity appears to focus on the importance of giving a principlcd justification for enforcing judicial decisions. Dworkin's concern with retroactivity derives from the belief that creating and applying new rights at the time of adjudication cannot be given a principled justification. See supra text accoinpanying notes 22-26 \& 49. Arguably, thercfore, ripple effect retroactivity with its consequential disruption of expectations and failure to provide notice is not the kind of retroactivity that would concern Dworkin.

My response has three strands. First, even if the unfairness of retroactivity gocs beyond the unfairness of upsetting expectations and failing to provide notice, surely expectation, notice and other rule of law virtues are at least part of the story. Dworkin's statements on this matter are not entirely clear, but he appears to agree that rule of law virtues are part, but not the entirety, of the poimt of enforcing preexisting rights. Id. at 336 ("An argument about legal rights, even in a hard case, is an argument abont something relevant to fairness; if the court believes that the plaintiff has a right, then it beheves, all things considered, including the question of surprise, that a decision against the plaintiff would be . . . unfair.") (emphasis added); see also id. at 325, 335-36. Thus, to the extent that the unfaimess of retroactivity imvolves additional factors, those factors may well make ripple effect retroactivity more objectionable. They will not, however, diminish the objcctions provided by inle of law concerns. At unost these fairness concerns, about which we may hope Dworkin will tell us more in the future, may sometimes outweigh the rule of law objcctions, justifying occasional episodes of ripple effect retroactivity.

Second, the moral force of the fairness of treating like cases alike, insofar as it extcnds beyond the demands of rationality resulting from the generality of reasons, is a difficult and elusive concept. It is yet more elusive when the cases that require like treatment oceur after the events being hitigated. For further discussion of this issue, see infra text accompanying notes 118-19 \& 127-29.

Third, to the extent that the judge's decision depends upon events (decisions) after the events 
virtues suggest normative grounds for enforcing the event rights. This is as we should expect, because the rule of law concerns are related to the desire to avoid retroactive application of law. Enforcing the event rights avoids the retroactivity engendered by the ripple effect argument.

Dworkin claims that the rights thesis has both prescriptive and descriptive aspects. ${ }^{74}$ If Dworkin modifies his theory to enforce event rights, he inay be able to save the prescriptive claim that this revised version of the rights thesis and right answer thesis is the theory of adjudication that judges should follow. However, in amending or furtlier developing his theory in this way, Dworkin will be forced to give up the theory's descriptive aspect. The normative rule of law arguments and the related argument from the unfairness of retroactive application of law suggest that judges should decide cases on the basis of the law existing at the time of the events being litigated. This is not the current practice of courts, however. Judges in general enforce the rights and law that exist at the time of adjudication precisely because of our conmitment to the Blackstonian declaratory theory that Dworkin defends. $^{75}$ Thus, the advocate of the rights thesis nuay adopt this position only at the expense of the claim that the theory is a correct description of judicial behavior.

It might be thought that the virtues of the revised theory justify giving up the descriptive claim. However, other factors militate aganist the proposed revision. First, the revision appears inconsistent with Dworkin's imtention to distinguish adjudication from legislation. ${ }^{76} \mathrm{Sec}-$ ond, the theoretical and practical difficulties of implementing the revision are considerable and perhaps insuperable.

The proposed event right revision entails giving judicial decisions prospective effect only. To say that a judge is to decide a case on the basis of the law existing at the time of the events is to say that the judge is to give no precedential force to decisions after the events. Froin the perspective of the subsequent decisions, this neans that the decisions

being litigated, the decision cannot be said to be an evaluation of the conduct of the litigants. Wlien judges take into account post-event decisions, their judgments appear to reflect forwardlooking considerations that are incounpatible with the overall thrust of Dworkin's claim that adjudication looks backward to preexisting rights and duties.

74. R. DworkiN, supra note 10, at 123. Although Dworkin is often thonght to be giving both an account of how judges sliould decide cases and of how they do decide cases, see, e.g., Lyons, supra note 34 , at 415 , he claims in his reply to Professor Soper that lie is not inaking a conceptual or descriptive claim but rather defending a conception of the concept "law." $R$. DworkIN, supra note 10, at 350-53. See generally id. at vii, 90, 123.

75. 1 W. Blackstone, Commentaries *69-70; Friedland, Prospective and Retrospective Judicial Lawmaking, 24 U. Toronto L.J. 170, 170 (1974); Mishkin, The Supreme Court, 1964 Term-Foreword: The High Court, The Great Writ and The Due Process of Time and Law, 79 HARV. L. REv. 56, 58-72 (1965).

76. R. DworkIN, supra note 10 , at 82 . 
only apply to cases whose events occurred after the decision. But that is equivalent to saying that decisions have only prospective effect. ${ }^{77}$

Prospective decisionmaking is, however, inconsistent with the overall purpose of Dworkin's rights thesis. The rights thesis distinguishes arguments of principle, which are appropriate for the judiciary, from arguments of policy, which are appropriate for the legislature. ${ }^{78}$ Dworkin's distinction between principle and policy, together with the claim that judicial decisions are to be justified by arguments of principle rather than pohicy, is imtended to capture what is distinctive about adjudication. ${ }^{79}$ But prospective overruling has been said to be particularly appropriate when the judge's decision appears legislative in character. The doctrine of prospective overruling is the legacy of legal reahsm, the doctrine that inamtains that judges legislate. ${ }^{80}$ For Dworkin to adopt that legacy of legal reahsin would indeed be ironic; it would undermine his thesis that judges are finding and declaring preexisting rights and not legislatimg new pohcy decisions.

Of course, this argument is merely suggestive and not conclusive. There may be grounds justifying prospective overruling that do not depend upon the view that judges legislate. The difficulty of implementing the revised event right theory suggests that we need not explore such grounds.

It is unlikely that the revised event right theory could be developed in detail, or utilized by judges if it could, for several reasons. First, the possibility of temporally extended events and transactions raises diffcult problems in determining the date of the law to be applied. These problems are compounded if several related but separable transactions are being hitigated and there are multiple issues. The prospect of ap-

77. Moreover, one must maintain an extreme view of prospective overruling. It would not be enough to simply adopt the common form of prospective overruling found in criminal procedure. See, e.g., Linkletter v. Walker, 381 U.S. 618 (1965); Beytagh, Ten Years of Non-Retroactivity: A Critique and a Proposal, 61 VA. L. Rev. 1557 (1975); Note, Retroactivity and ProspectivityCurrent Trends in the Law of Retroactive Decision-Making, 7 WAKE FOREST L. REv. 500 (1971). This more common form of prospective decisionmaking will, by definition, affect those cases whose events oceurred prior to the prospective decision but whose final adjudication did not. See, e.g. , Linkletter, 381 U.S. at 622-29; Molitor v. Kaneland Community Unit Dist. No. 302, 18 111. 2d 11, 27, 163 N.E.2d 89, 96-97 (1959). See generally Mishkin, supra note 75; Note, Prospective Overruling and Retroactive Application in the Federal Courls, 71 YALE L.J. 907 (1962) (Dean James O. Freedman's student note) [heremafter cited as Note, Prospecive Overrulings]. Because of its limited focus, this form of prospective overruling allows the possibility of the ripple effect, and its consequent retroactive application of law. This is not surprising simce it is designed to allow for limited retroactivity. Thus, Dworkin would require an extreme version of prospective overruling to avoid the possibility of retroactivity resulting from the ripple effect.

78. R. Dworkin, supra note 10 , at $82-86,90-94$.

79. Id. at 82. See generally id. at 81-130.

80. See, e.g., Friedland, supra note 75, at 170-71; Levy, Realis/ Jurisprudence and Prospective Overruling, 109 U. PA. L. REv. 1, 1-2, 6, 27-30 (1960); Note, Prospective Overrulings, supra note 77, at $910-11$. 
plying the law at different times to different but related aspects of a counphicated transaction raises unappealing complexity. Further and perhaps insuperable coinplexity arises if it is possible to analyze the overall transaction in inultiple ways into different temporal coinponents. Unless we can be sure that one temporal analysis will be superior to all others, we will need rules to choose among the various analyses. More important, it is unclear what precedential effect should be given to a decision that apphies law from many time periods, law that by definition ${ }^{81}$ differs from the law that would be applied to an event that occurred at the time of adjudication if higated at that time.

The problenn of determining precedential effect is telling agaimst the event right revision. It apples not only to cases involving teinporally extended transactions, but to all cases. This point can be illustrated by the simple privity of contract example discussed above. ${ }^{82}$ Suppose the history of the law in solne jurisdiction is that as of year 1 , there is liability at one step removed but not at six. In year 2, a threestep case is adjudicated and the court correctly finds liability. In year 4, a four-step case arising from events in year 1 colnes to trial. Under the unrevised rights thesis, there is ripple effect retroactivity. The defendant, who would not have been hable had his trial preceded the threestep case, is now hable. Property would be redistributed due to new rights created after the events. The four-step defendant may even have rehed upon his correct belief that when he acted in year 1 he was not hable.

Consider the result under the revised event right theory. Because the event rights imply no hability, the defendant prevails. The law after these cases would be that one- to three-step defendants are hable while four-step and "higher" defendants are not hable. Or is it? Suppose further four-step cases arise. In case $A$, the events occurred in year 3 , after the decision in the three-step case and before the decision in the four-step case. It would be a mistake to think that since $A$ is a four-step case, the year 4 four-step case is dispositive and the defendant prevails. Under the event rights in year 3, when case $A$ arose, a fourstep defendant would have been held hable, because four is closer to three than to six. So the defendant in case $A$ loses. We now have two four-step cases; in one the defendant prevails, in the other the plaintiff prevails. What is the applicable law when case $B$, arising from events after $A$ is adjudicated, coines to trial? Do we follow the result in case $A$ and find the defendant hable? Or do we follow the year 4 four-step

81. The event right revision of the rights thesis will only make a difference when there would have been a ripple effect under the unrevised rights thesis. That is, only when the event rights differ from the adjudication rights.

82. See supra text accompanying notes $64-67$. 
case, and find the defendant not liable? A solution based upon the fact that $A$ was decided later will not do, since we can change the liypothetical by replacing case $A$ with case $A^{\prime}$ which arises froin facts at the same time as $A$, but is decided simultaneously with the year 4 four-step case and correctly finds liability.

The example can be expanded endlessly, creating further difficulties in determining the force of precedent in the event right revision. The theoretically thorny problems that arise may be impossible to resolve. ${ }^{83}$ Further, even if they could be resolved, the resolution would be too coinphicated for judges to utilize. This practical problem highlights a respect in which Dworkin's theory of adjudication may be incoinplete ${ }^{84}$ A coinplete theory inust include not only an account of what judges should do and in fact do, but also an explanation of how it is possible for thein to adjudicate as they do and as they should. More generally, a coinplete theory inust acknowledge and describe the limits of what is humanly possible in judicial decisionmaking. ${ }^{85}$

The attempt to avoid the ripple effect arguinent ineets with insuperable difficulties. The resulting retroactivity cannot be avoided. Dworkin's theory offends the saine rule of law and fairness prohibitions as Hart's positivisin. Reappraisal of the rights thesis is in order.

III

Responses to the Ripple EFFect ARgument

This section addresses two potential responses to the ripple effcct's impact on Dworkin's jurisprudence. First, one could argue that retroactivity is a less serious problein for Dworkin's theory than for Hart's. Second, one could argue that the ripple effect arguinent is invalid. This latter objection could take two forms: the first form begins with the premise that primciples never change; the second with the premise that the "right answer" never changes.

The first line of defense open to the rights theorist is to claim that there is far less retroactivity in the rights thesis than under Hart's positivist doctrime of discretion. Ripple effect retroactivity occurs only in those few hard cases where a ripple effect has changed a dispositive legal right. By contrast, on Hart's theory, all hard cases involve retroactive apphication of judicially created law. Thus, while the rights the-

83. A glimmer of the difficulties involved in constructing such a theory can be extracted from the discussion of a not totally dissimilar problem in Munzer, Retroactive Law, $6 \mathrm{~J}$. Legal STUD. 373, $389 \mathrm{n} .21$ (1977). The theory would likely be at least as complicated as double-indexcd tense logics. See generally N. Rescher \& A. Urquhart, Temporal Logic (1971); A. Prior, Past, Present AND Future (1967).

84. See supra note 74 and accompanying text.

85. Moore, supra note 14 , at 154. 
sis does not totally eliminate retroactivity, despite Dworkin's ambition, it allows very little retroactivity, and fares significantly better on this score than does positivism. The ripple effect may dent the rights theorist's armor, but does no real damage. ${ }^{86}$

The proposed defense cannot be accepted, for several reasons. First, it understates the pervasiveness of the prohibition against retroactivity in Dworkin's theory. ${ }^{87}$ Second, although ripple effect retroactivity may occur less frequently than hard case retroactivity im Hart's positivism and is in this sense a less serious criticism of the rights thesis, in another sense, it is a deeper criticism.

Because Hart does not maintain the right answer thesis, he can claim that some propositions of law are undecided in the sense that they are neither true nor false. These are the dispositive propositions of future hard cases. Prior to the judge's decision, the proposition is neither true nor false. As a result of the decision, the proposition may be true thereafter. Nonetheless, the unsuccessful litigant cannot clann that the law has been changed on him. What was formerly an open question was decided against him, as he knew it might. The higant has been subjected to retroactive apphication of new law, but not to retroactive apphication of a result opposite to that which would have been required, by law, at the time of the events.

By contrast, the right answer thesis demies that, in practice, ${ }^{88}$ any propositions of law are neither true nor false. By definition, ${ }^{89}$ ripple effects change legal propositions from true to false, and vice versa. If the right answer thesis is correct, ripple effects sometimes cause retroactive applications of the result opposite to that required by the law ex-

86. The claim that there are few instances of ripple effect retroactivity because retroactivity only occurs when ripple effects change dispositive legal rights is difficult to assess because our knowledge of the operation of precedent is abstract and general, as are Dworkin's expositions of the rights thesis. It cannot, however, be excluded a priori that law is a seamless web and that, in theory, every new decision affects, at least minimally, every legal proposition. Ripple effects could result from accumulation of minimal changes, in addition to dramatic changes, thereby increasing the potential for retroactivity.

Shifting focus from Dworkin's pure theory, at least two other sources of retroactivity may exist in practice. First, to the extent, if any, that judges' theories of rights are consequentialist, $\mathbf{R}$. DwORKIN, supra note 10 , at 294-301 \& passim, rights may depend in part upon instruinental values. If circumstances change so that bestowing a right upon the litigant no longer results in the desired consequence, the right may no Ionger exist.

Second, Dworkin concedes that reasonable judges will often disagree about what the right answers are. In practice, therefore, judges will often decide cases differently than Dworkin's superhuman judge Hercules would lave. These judicial "errors" will result in failure to enforce preexisting rights. Insofar as there is more disagreement about right answers in the rights thesis than about correct judicial behavior in positivisin, the rights thesis will result in greater retroactivity from reasonable judicial mistakes.

87. See supra text accompanying notes $22-26$.

88. See supra note 28 and accompanying text.

89. See supra text accompanying notes $61-63,65-67$. 
isting at the time of the events in issue. In this sense, the litigant is subjected to retroactive application of law that "overrules" the previously required result. If the right answer thesis is correct, the frustration of the litigant's expectations appears to be inore severe, and the unfairness of retroactive application of law greater, because the litigant's right is in soine sense unore vested, or tangible.

Because ripple effect retroactivity, when it occurs, constitutes a nore serious defect for Dworkin's theory than the retroactivity engendered by hard cases does for Hart's, advocates of the rights thesis unust meet the challenge of justifying ripple effect retroactivity. It is possible that their response will justify retroactivity in hard cases generally, thus casting a new light on Dworkin's criticisin of positivisin. Even if the response does not justify retroactivity in all hard cases, it may be the wedge that opens the door to a justification that does. We cannot fully assess Dworkin's jurisprudence, and his criticism of Hart, until nore is known about the possible justifications for ripple effect retroactivity, and retroactivity in general. ${ }^{90}$

The impact of ripple effect retroactivity on the rights thesis and the debate between Hart and Dworkin should not be underestimated. But neither should it be overestimated. Dworkin's attack on positivism is rich and subtle, with many prongs. ${ }^{91}$ If the rights thesis is not superior to positivisin because it successfully avoids retroactive application of law, it inay still be preferable for other reasons. For example, the rights theorist could deeinphasize the undesirability of retroactivity and focus on Dworkin's related point that Hart's positivism requires, while the rights thesis does not permit, that inost undemocratic of acts: the exercise of judicial discretion. ${ }^{92}$ The initial attractiveness of this idea fades under the tension between the denocratic separation of powers foundation for rejecting judicial discretion ${ }^{93}$ and the pervasive undemocratic flavor of Dworkin's commitunent to some form of natural law, ${ }^{94}$ to the existence of best answers to inoral and political questions, ${ }^{95}$ and to the appropriateness of judges making noral and political decisions. ${ }^{96}$ Even if the retreat from retroactivity to discretion does not seem promising, the general point is worth repeating: Dworkin's other arguinents

90. One place to begin is with Professor Munzer's recent article $A$ Theory of Retroactive Legislation, 61 TEX. L. REV. 425 (1982). Other valuable writings include Mishkin, supra note 75; Munzer, supra note 83; Note, Prospective Overrulings, supra note 77.

91. See R. DWORKIN, supra note 10, at 14-130.

92. Id. at 17, 31-39, 84, 279.

93. See id.

94. See Dworkin, "Natural" Law, supra note 12.

95. See, e.g., R. Dworkin, supra note 10, at 279-90; Dworkin, Law as Interpretation, 60

TEX. L. Rev. 527, 546 (1982). See generally Dworkin, No Right Answer?, supra note 12.

96. R. DwORKIN, supra note 10, at 123-30. 
against positivism, besides the argument that it leads to unjustified retroactivity, are quite forceful and inay theinselves be decisive. ${ }^{97}$

Rather than minimize the seriousness of ripple effect retroactivity for Dworkin, one might instead seek to rebut the ripple effect argument itself. One possible refutation can take either of two forms. ${ }^{98}$ Neither form succeeds because each involves giving up the dominant notion of precedent: the view that prior decisions provide reasons that later deci-

97. The significance of the ripple effect for the dispute between Hart and Dworkin may be illustrated by reference to the controversy about the relationship between law and morals. Dworkin has developed two major (and several minor) criticisms of the positivist doctrine of the separation of law and morals. These criticisms may be labeled the argunient from controversy and the argument from the possibility of overruling. It has generally been thought that the argument from controversy is the more forceful of the two nuajor arguments. Dworkin, among others, has written more expansively and exphicitly on it than on the argument from overruling. See $\mathrm{R}$. DworkIN, supra note 10 passim; see also sources cited supra note 34 . The argument from controversy asserts that even in a hard case, where the result is controversial, there are preexisting legal rights. These legal rights cannot be fully supported simply by legal rules simce, by definition, we are considering a hard case. Thus, there must be nonrule legal standards-call them principlesthat support the rights.

The claim that there arc preexisting legal rights in hard cases is in turn supported by two main argunients and several minor arguments. The minor arguments mclude the denial that judg$\mathrm{mg}$ in hard cases is a two-step process, as positivism apparently asserts, $\mathrm{R}$. DworkIN, supra note 10 , at 86,112 , and the assertion that our linguistic practices presuppose that even in hard cases, legal arguments are arguments of entitlement. $I d$. at 81 . We argue to the judge that the law is $P$, not that the law should be $P$.

In the main, however, the argunent for the preexistence of rights in the face of controversy is supported by objections to retroactive apphcation of law, see supra text accompanying notes 2226 , and to the exercise of judicial discretion. The objections to judicial discretion derive in part from the doctrine of separation of powers and similar democratic concerns. R. DworkIN, supra note 10 , at 84 .

The second major criticism of the doctrine of the separation of law and morals is the argument from the possibility of overruling. The best explanation of the practice of overruling of prior precedent and justification of decisions that overrule is that the substantive (legal/moral) principles recominending the new rule outweigh the substantive (legal/moral) principles favoring the old rule plus the conservative rule of law principles that disfavor change. Id. at 37, 44, 65-68. See generally id. at 110-23. Similarly, the justification of the decision to follow precedent must be that the principles supporting the old rule outweigh the principles recominending a change. $I d$. at 38 .

The impact of ripple effect rctroactivity on Dworkin's assertion of an essential coumection between law and morality can be tentatively described as follows. Proponents of the doctrine of the separation of law and morals will view the ripple effect argument as a central part of the defense against Dworkin's attack. It significantly diminishes the force of Dworkin's central criticisn, the argument from controversy, by deflating the objection to retroactivity, leaving that argument supported by the less persuasive separation of powers objection to judicial discretion and the minor arguments related above. From the perspective of the defender of an essential connection between law and morality, or of Dworkin's rights thesis, the ripple effect argument will suggest that the argument fron overruling may be a more secure foundation than the currently more popular argument froin controversy. The ripple effect argument therefore suggests that further development and analysis of the argument from overruling is warranted.

98. One or both of these forms of the objection have been advanced at nearly every presentation of this Article. These objections appear to derive from the imtuition that the right answer thesis is straightforwardly imconsistent with the possibility that future decisions will change the law by the operation of the doctrine of precedent. 
sions be decided in like ways, even if the prior case was decided incorrectly.

The first form of the objection starts from the preinise that principles never change, thus preventing the ripple effect at its source. Since principles remain constant, the objection continues, so do litigants' rights. There are no ripple effects and resulting retroactive applications of law.

While a theory of legal reasoning that employs unchanging principles may be possible, it does not appear to be Dworkin's theory. For Dworkin, legal principles are those principles that provide the best explanation and justification of the settled law in the jurisdiction. ${ }^{99}$ Which principles are authoritative depends upon two factors-institutional history and moral appeal. With at most occasional exceptions, the principles that best explain and justify two different sets of precedents will themselves differ. ${ }^{100}$ To completely avoid the possibility of

99. See supra note 67.

100. If the two sets of precedents (and institutional facts) differ only in that the latter contains a decision logically deducible from the principles that best explain and justify the first set, it may well be that the latter set will be explained and justified by the same principles. If, however, the latter set of precedents contains an additional decision that is not logically deducible from the principles that explain and justify the first set of precedents, but merely coheres better with those principles than the opposite decision does, then most likely the principles that best explain and justify the later, enlarged set of precedents will differ. At the very least, the weight of the principles will differ because principles that recommend the additional decision will be accorded extra weight. For discussion of the concept of weight, see supra note 45 and accoinpanying text.

That different institutional histories will generate different principles can be seen by considering theory construction in science. In science, data or observations play the role of institutional history, while axioms or first principles play the role of authoritative principles. It cannot be seriously entertained that any two sets of data can be explained by precisely the same set of axioms or first principles. Nor could it plausibly be mamtamed that adding one additional piece of data (that is not deducible froin the best theory of that data) would not sometimes require at least minor revision of the basic principles. Nor could one plausibly maintain that the addition of one piece of data would never rcquire revision of the basic principles because only the addition of large sets of data could have that effect. The addition of large amounts of data can, and in gencral will, be achieved by successive additions of single picces of data. Thus, large amounts of additional data can occasion a change in principles only if addition of individual pieces of data can.

The hypothesis that adding one piece of data would never occasion a change in the principles is false because it leads to absurd conclusions. The hypothesis entails that any two sets of data that overlap, even in the shightest degree, are best explained by the same principles. By the hypothesis, the data sets $\left\{a_{1}\right\},\left\{a_{1}, a_{2}\right\}$, and $\left\{a_{1}, b_{1}\right\}$ are all best explained by the same set of principles since the latter two sets differ from the first set only by addition of one piece of data. Applying the hypothesis again, the data sets $\left\{a_{1}, a_{2}, a_{3}\right\}$ and $\left\{a_{1}, b_{1}, b_{2}\right\}$ are also best explained by the same principles. By repeated application of the hypothesis $\left\{a_{1}\right\},\left\{a_{1}, a_{2}, a_{3}, \ldots\right.$ an $\}$ and $\left\{a_{1}, b_{1}, b_{2}, \ldots b n\right\}$ are best explained by the same principles, for any $n$. The liypothesis robs the notion of explanation of its content and must be rejected.

Adinittedly, the relationship between authoritative principles and institutional history (including prior precedents) is in soine ways inore complex in Dworkin's theory of adjudication than the correlative relationship in science. Legal principles inust not only explain, but must also justify the legal "data." The theory of mistakes allows the judge to discount a few pieces of legal data. Soine precedents may be ignored if they would no longer cominand assent in the legal 
ripple effect retroactivity, one would have to take the highly implausible position that principles never change no matter how extensively institutional history changes. Even if a new line of cases were to develop, or an old line were overruled, the objection would require that the old principles provide the best explanation of the new law.

It may be argued that any well-developed legal system, such as those in the present day United States and England, already contains all the principles that are likely ever to be authoritative. ${ }^{101}$ Even if no new principles arise, however, an adequate explanation of the new precedents would require revision of the relative weights ${ }^{102}$ of the legal principles. Moreover, even if the "grand rights" of pohtical rhetoric ${ }^{103}$ and the principles that describe them ${ }^{104}$ do not change, more "concrete rights" 105 and principles will change in response to common law development, and that is all that is needed for the ripple effect. To deny that law and legal rights change at all in response to new decisions is to deny that legal rights are, at least in part, determined by settled law. It is thus not only to deny one of Dworkin's major theses, but more fundamentally to give up the dominant conception of precedent altogether. ${ }^{106}$

The second forn of the objection begims from the preimse that the right answer thesis must imply that the right answers are already present at the beginning of any period of common law development. In the

community. See supra notes 55-57 and accompanying text. See generally R. DworkIN, supra note 10, at 159-68 (discussing the difference between natural (scientific) and constructive (legal) models of theory construction). Although these additional elements require complications in the argument rejecting the claim that legal principles do not change in consequence of new decisions, the basic thrust of the argument remains secure. To the extent that explanation plays a role, even if diminished, in the relationship between legal principles and legal data, changes in data will occasion changes im principles.

101. Dworkin's remarks in a recent article about density of developed legal systems and the right answer thesis may be urged-probably incorrectly-in support of this claim. Dworkin, No Right Answer?, supra note 12, at 30 \& passim.

102. For a discussion of Dworkin's notion of the weight of principles, see supra note 45 and accompanying text.

103. See R. DworkIN, supra note 10, at 89.

104. Id. at 90 .

105. Id. at $89,93-94$.

106. 1 do not deny that the ripple effect argument can be circumvented by denying its meager premises. The ripple effect argument shows that legal systems enbodying the dommant conception of precedent retroactively apply law. The ripple effect argunent applies to coherence theories because they provide a particular explanation of how precedent operates. Legal systems that do not imclude the domimant notion of precedent are not subject to the ripple effect. But the argument does not pretend that they are. Of course, the Anglo-American legal systems and many others undoubtedly do include the authority conception of precedent. Some sections of the French Civil Code suggest that the doctrine of precedent does not apply in the French legal system. See CODE CIVIL $\$ 5$ (Fr. 1895) ("Judges are not allowed to decide cases submitted to them by way of general and settled decisions."). It is unlikely that $\S 5$ lias been strictly followed. 
above example, ${ }^{107}$ this form of the objection can be stated as follows. If after the judge exphicitly decides that $Q$, the new best theory of settled law ( $S T L$ ) requires that not- $X$ be true, it cannot be the case, as the example suggested, that the prior best theory of settled law $(S T L)$ required that $X$ be true. Not- $X$ always was and always will be the case, if the right answer thesis holds. This claim involves, once agam, the abandonment of the dominant conception of precedent. It requires that the law never change in consequence of judicial decisions.

For the objection to be sustamed, it must provide a means for deciding among possible complete coherent contmuations of the settled legal truths. The pair $Q$ and not- $X$ is not the only possible coherent contmuation. If $X$ were to come up for decision before $Q$ the judge should decide that $X$, thereby occasioning the truth of not- $Q .{ }^{108}$ Thus, the pair $X$ and not $Q$ is also a possible coherent continuation. If right answers never change, we must have a method for choosing whether the right answers mclude $Q$ and not- $X$ or, in the alternative, $X$ and not$Q$. Further, the method inust determine the truth value not only for $Q$ and $X$ but also for all other possible legal propositions. But wholesale and final determination of the truth or falsity of all possible legal propositions leaves no room for the operation of the dominant notion of precedent. The objection purchases unchanging right answers and avoidance of the ripple effect at the cost of dispensing with the doctrine of precedent.

Further, this objection nnsunderstands the right answer thesis in Dworkin's theory. While at each point in time there are right answers to all or nearly all ${ }^{109}$ legal issues, the right answer that is given may not be the same as that which would be given at another poimt in time, in consequence of changes im institutional history. Part of the poimt of rigidly separatmg legal truths into two classes, the settled law $(S L)$ and the coherence consequences $(U C)$, is to highlight the greater imstability of legal truth when it results from better coherence with the best theory of settled law rather than from inembership in the set of propositions comprismg the settled law.

This is perhaps an appropriate place to mention one respect in which the rigid separation of legal truths into settled law and coherence consequences may be misleading. The rigid separation suggests that the positivist or formalist claim that the results in easy cases can be

107. See supra text accompanying notes $61-63$.

108. This is premised on the plausible hypothesis that $Q$ and $X$ are incoherent. That incoherence best explains why the addition of $Q$ occasions the falsity of $X$. It is possible that the addition of $Q$ will occasion the falsity of $X$ even though $Q$ and $X$ are not incoherent due to "accidental" aspects of the methodology of constructing the soundest theory of the law. The text considers an mstance of the more likely case of at least partial incompatibility between $Q$ and $X$.

109. See supra note 28 and accompanying text. 
logically deduced ${ }^{110}$ is accepted by the proponent of the rights thesis. The rigid separation further suggests that Dworkin criticizes positivism because it is incomplete: positivism's theory of easy cases must be supplemented by a further theory of hard cases, mvolving coherence rather than deduction, and it must be recognized that there are more hard cases than the positivist might lead us to beheve. Yet Dworkin would resist these suggestions because his criticism of positivism is more radical. Dworkin believes that positivism's theory of easy cases-in the area of settled law-is mcorrect, and not merely incomplete. Decisions m easy cases are justified not because they can be deduced from legal rules or settled law but because those decisions cohere or fit better with the soundest theory of law than the opposite decision. The positivist's deduction appears from this perspective as an easy case because it is a strong form of coherence. The difference between judicial decisions in the area of settled law and in the area of coherence consequences is one of degree and not kind.

That the difference is one of degree and not kind does not undercut the ripple effect argument. Even if the "boundary" between settled law and other legal propositions is vague or uncertam, it is still true that judicial decisions will affect the location of propositions decided by the court relative to that boundary, thereby occasioning ripple effects in the full universe of legal propositions. Put differently, judicial decisions will change the degree to which legal propositions are settled, thereby occasioning ripple effects.

\section{IV}

\section{CONSERVATIVE THEORIES AND THE RIPPLE EFFECT}

\section{A. Legal Reasoning and the Ripple Effect}

The ripple effect argument causes particular problems for Dworkin because of his commitment to the enforcement of preexisting rights and the right answer thesis. However, the ripple effect will also occur in theories of adjudication not committed to these positions.

Imagine, for example, a coherence theory of legal reasoning that demies the right answer thesis. One such theory might hold that some hard cases have right answers but others do not. ${ }^{111}$ The hard cases that have right answers are those where the prevailing litigant's position coheres significantly better with the best theory of settled law than the

110. See Coleman, Negative and Positive Positivism, supra note 34, at $164 \mathrm{n} .15$; Moore, supra note 14 , at $155-56$.

111. Some theorists have claimed that Dworkin holds this view. Galis, The Real and Unrefuted Rights Thesis, 42 PHIL. Rev. 197, 218-21 (1983); see also Lyons, Justification and Judicial Responsibility, 72 CALlF. L. REv. 178, $180 \mathrm{n} .3$ (1984) (asserting that Dworkin only claims that sometimes there are right answers). But see supra note 28. 
opponent's position does. If the litigants' positions are equally compatible with settled law, or one litigant's position provides only a slightly better fit with settled law, then the case has no single right answer. ${ }^{12}$ Rather, the judge may exercise discretion and decide for either litigant. ${ }^{113}$ This theory might be labeled the "ping-pong" theory of adjudication: a litigant must defeat his opponent by at least "two points" in order to have a right to a decision in his favor.

Legal propositions may be categorized as follows in the ping-pong coherence theory. First, there are the propositions of settled law. These roughly correspond to the prevailing parties' positions in easy cases, to those legal truths within Hart's core of settled meaning, ${ }^{114}$ and to the formalists' heaven where judicial decisions can be deductively justified. ${ }^{115}$ Correlative to this class of legal truths are the settled falsehoods, the contradictories of settled truths, the contentions of losing parties in easy cases. Second, there are those legal propositions that are true because they cohere sufficiently better with the settled law than their negations do. These are the implicit legal truths. Correlative to the class of implicit truths is the class of the implicit truths' contradictories, the implicit falsehoods that cohere significantly lcss well with settled law than do their negations. Finally, there is the class of open questions, consisting of propositions that fit the settled law to approximately the same degree as their negations.

It should be clear that ripple effects will occur in this ping-pong theory, just as they do in the rights thesis. ${ }^{116}$ Some ripple effects will result in formerly open questions becoming either implicit coherence truths or implicit coherence falsehoods. When this happens, an adversely affected litigant cannot claim that the law has been "overruled," 117 because by definition the dispositive legal proposition was previously open. The litigant is not subjected to a retroactive change that denies him a right to prevail that he previously possessed, as is the

112. For ease of exposition only, this Article sometimes discusses coherence (fit) with the settled law, and not with the best theory of the settled law, the best justification of the settled law, or the soundest theory of law. This abbreviated terminology is not intended to suggest a lesser role for justification. The arguments in this Section assume only that explanation plays a role in the coherence theory, and apply whatever the exact tradeoff between explanation and justification.

113. The theory may be filled out in ways that constrain the exercise of discretion by requiring that the judge consider only some kinds of additional standards, or by requiring that the additional standards used be principled, neutral, and the like. For present purposes, these refinements are irrelevant.

114. H.L.A. HART, supra note 16 at 120, 124-32; see also Hart, Positivism and the Separation of Law and Morals, 71 HARV. L. REv. 593, 607-10 (1958).

115. See Moore, supra note 14, at 155-56; see also Zane, German Legal Philosophy, $16 \mathrm{MicH}$. L. REv. 287, 338 (1918).

116. See supra text accompanying notes 61-63.

117. See the analogous discussion of hard case retroactivity in Hart's positivism, supra text accompanying notes $86-90$. 
case with ripple effects in a theory that maintains the right answer thesis. In this respect, this litigant is subjected to less unfairness than his counterpart in a jurisdiction adhering to the right answer thesis. Nor can the litigant fairly claim complete surprise, or justified reliance, because he should have known that the dispositive legal proposition could have been decided either way.

Nonetheless, something here is unfair, or at least arbitrary. Because legal decisions that cohere better with the opponent's position than with the litigant's have been decided after the conduct in issue, the litigant has lost the right to persuade the judge to exercise discretion in his favor. ${ }^{118}$ Arbitrary historical facts compel a decision against him because they enlarge the standards that the judge is obligated to consult. The litigant has lost the right to have his rights determined by appeal to a particular limited class of standards. ${ }^{119}$

There is something morally unsettling about the contingencies that determine which new standards will be applied. Had cases cohering better with the litigant's position been decided after the events and prior to trial, they might have compelled a decision in his favor. Moreover, the litigant is being subjected to retroactive application of new law, although the unfairness of that retroactivity is mitigated because new law had to be created to answer what by definition was previously an open question.

However, the ripple effect arguinent's applicability to this pingpong coherence theory extends beyond the attenuated unfairness resultimg when ripple effects change open questions to implicit coherence legal truths and falsehoods, and vice versa. Some litigants will be subject to ripple effect "overrulings" that exactly parallel the ripple effects that occur in Dworkin's rights thesis. ${ }^{120}$ The percentage of ripple effects that cause overrulings, rather than determinations of previously open questions, will depend upon the relative sizes of the class of implicit, coherence truths and the class of open questions. ${ }^{121}$ In turn, the difference in the sizes of these classes will depend upon how mucli greater the fit with settled law must be in order for a proposition to be a coherence truth rather than an open question. ${ }^{122}$

118. This claim depends upon how, in this theory, open questions are decided and may require revision if judicial discretion is limited. See supra note 113.

119. Because of ripple effects, the case will be decided in part on the basis of the precedential force of cases decided after the conduct in issue. But see supra note 118.

120. See supra text accompanying notes $61-63,65-67,87-90$.

121. There will also be occasional cases where settled legal truths become falsehoods and vice versa. This is unlikely to be a significant factor, however.

122. On one explication of the Quinean metaphor, it will also depend on the number and strength of connections between dispositive propositions and other legal truths. More generally, it will depend upon how the notion of coherence is developed. 
Thus, the ripple effect argument apphes, within the somewhat restricted class of nonopen legal propositions, with the same force that it does to Dworkin's rights thesis. The move to a theory that denies the right answer thesis merely restricts the most morally objectionable ripple effects to that portion of the law where there are right answers; it allows for less disturbing ripple effects in those areas of the law without right answers. Indeed, since nothing in the argument has relied on the details of any coherence theory, it should be clear that ripple effects will occur in all coherence theories, with or without the right answer thesis, with or without the ping-pong threshold explanation for denying the right answer thesis.

The only way to avoid the more objectionable ripple effect "overrulings" would be to deny that there are any right answers outside the area of settled law. It would be to assert that the right answers encompass only decisions deducible from settled legal rules. Besides being grossly implausible, this formahist position, ${ }^{123}$ in effect, denies coherence any role in adjudication. It is thus the exception that proves the rule: coherence theories lead to ripple effect retroactivity and "overrulings."

\section{B. The Impact of the Ripple Effect on Coherence Theories}

Assuming that the ripple effect argument holds for all substantial coherence theories, ${ }^{124}$ we should assess the resulting jurisprudential problems. The ripple effect argument challenges legal theorists to avoid or justify the resulting retroactivity. Ripple effect retroactivity results from the conservative element in legal reasoning: precedent. A linear ordering problem also arises from this conservative element. Legal theorists must also justify the moral arbitrariness resulting from this linear ordermg problem.

\section{Retroactivity}

It has been argued that "overrulings," and not mere retroactive applications of newly created laws that fill the gaps, will occur in other coherence theories, as they will in the rights thesis. Nonetheless, it might be thought that the undesirability of retroactivity is overeinphasized in Dworkin's jurisprudence, and is no more than minimally troubling once Dworkin's theoretical commitments are abandoned.

Consider, for example, a utilitarian legal theorist. The utilitarian will advocate the retroactive application of a new rule whenever the

123. The formalist claim that the legal propositions necessary for judicial decisions are deducible from legal rules and facts does not accurately express the formalist position. One needs to add that the contradictory of the proposition cannot also be deduced.

124. See supro text accompanying notes 112-23. 
overall utility of that application exceeds the utility of applying the prior law, counting, among other things, the disutility of upsetting justified expectations, reliance, and the like. Retroactivity will be justified whenever its overall consequences are better than the consequences of avoiding retroactivity. Why should legal theorists who reject the rights thesis be concerned about retroactivity?

In part, retroactivity is troublesome because it conflicts with the rule of law virtues of satisfying justified expectations, providing citizens with notice of the law so that they may efficiently plan their affairs, and similar concerns. One could argue that these concerns are undercut by the hitigant's awareness that her conduct will be adjudicated on the basis of the applicable law at the time of adjudication. Since the litigant realizes that her conduct may be judged under law differing from that im effect at the time she acted, any purported reliance upon the then existing law is arguably misplaced and thus unjustified.

This response has an air of circularity about it: the litigant's reliance is unreasonable only if legal practice is assumed to require enforcement of adjudication rights, and not event rights. In addition to being circular, the argument from the litigant's reasonable expectations overstates the degree to which the post-conduct law is written on a blank slate. Slow change in legal doctrine should be anticipated, but major or rapid changes may be unforeseeable. On balance, the argument from reasonable expectation of legal change dilutes, but does not totally eliminate, the force of the rule of law arguments for the unfairness of retroactive application of law. ${ }^{125}$

However, the objection to retroactivity goes beyond rule of law concerns. More fundamentally, retroactivity raises a conceptual puzzle that results in a moral quandary. It is conceptually impossible to "break" a law that did not exist when one acted. When judges create and retroactively apply "laws" as a consequence of the ripple effect, the justification for enforcing the judgment cannot be that the defendant violated the law. She may have acted contrary to a rule that later became the law, but that is another inatter. Redistributing her property to the plaintiff cannot be justified on the ground that she violated the plaintiff's rights. Of course, redistributive acts are often justified on egahtarian or other fairness grounds. But social decisions to redistribute property are thought by many to be within the competence and authority of the legislature, not the judiciary. Nor is there any a priori reason to think that ripple effect redistributions would aid any particu-

125. Professor Gary Schwartz has discussed some similar concerns in the context of tort law. See Schwartz, New Products, Old Products, Evolving Law, Retroactive Law, 58 N.Y.U. L. REv. 796, 817-18 \& passim (1983). 
lar economic or social group since ripple effects can help defendants as well as plaintiffs.

No theory of adjudication will be fully satisfactory unless it can justify the retroactive applications of judicially created "law" resulting from the ripple effect, or successfully avoid them. Thus, the ripple effect argument poses a challenge to legal theory generally, and especially to coherence theorists. Because Dworkin is acutely aware of this conceptual puzzle and related moral quandary, ${ }^{126}$ he has committed the rights thesis to the enforcement of preexisting law and has made the atteinpt to avoid retroactivity a central part of that theory. Responding to that emphasis, my criticism of the rights thesis focused on the retroactivity resulting froin ripple effects. In shifting focus from the rights thesis to coherence theories of legal reasoning inore generally conceived, another morally troubling issue is raised: the linear ordering problem.

\section{Precedent and the Linear Order of Decisions}

The ripple effect will occur in any step-by-step technique for generating coherence sets that includes a principle of conservation. By a principle of conservation, I inean that the set's history of element inclusion is a factor in determining whether any current element is included. In other words, the order in which elements are considered determines what gets in the set because it determines what is already there to cohere (or fail to cohere) with. In adjudication, the doctrine of precedent supphies the conservative aspect: legal truths depend in part on prior legal decisions. The inere historical fact of a prior decision influences the decisions in later cases, and thus the law, because it enlarges the settled law with which later decisions must cohere. What the law is therefore depends on the linear order in which cases have been decided. ${ }^{127}$ Precedent thus generates not only ripple effects but more generally, and perhaps more significantly, the linear ordering problein.

Ripple effects highlight one respect in which the dominant theory of precedent is morally arbitrary. According to that theory, prior decisions are to be accorded weight which may influence the outcomes in later cases merely by virtue of the fact that the decisions have occurred.

126. See supra quotes from Dworkin accompanying notes 25,26 ; see also text accompanying notes $21-26,47-49$.

127. The linear ordering problein parallels, but is not identical to, results on agenda influence in recent literature on public choice. See generally Easterbrook, Ways of Criticizing the Court, 95 HARV. L. Rev. 802 (1982); Levine \& Plott, Agenda Infiuence and tis Implications, 63 V.. L. Rev. 561 (1977); Spitzer, Multicriteria Choice Processes: An Application of Public Choice Theory to Bakke, the FCC, and the Courts, 88 YALE L.J. 717 (1979). The ageuda influence public choice literature is a natural extension of $\mathrm{K}$. ARRow, Social ChOICE AND Individual Values (2d cd. 1963). 
The historical fact of the decision, even if it was requircd by prior law and could have been predicted with near certainty, increases its weight in later determinations of what the law is. Yet, from the perspective of a citizen whose conduct inay later result in litigation, the historical fact of which cases are decided after his conduct but before his case is adjudicated appears to be morally arbitrary. To allow such historical facts to affect, or determine, the outcoine of a case, as happens when there is a dispositive ripple effect, is therefore inorally arbitrary.

Generalizing the point beyond ripple effects in dispositive legal issues currently being litigated highliglits the inoral dilemma ensuing froin the linear ordering problen. Consider the simple privity of contract example once more. ${ }^{128}$ When the cases find privity and liability at one step, but not at six, the implicit law is that there is liability in twoand three-step cases but not in four- and five-step cases. If at that time, a three-step case and a four-step case are simultaneously being litigated, the outcoine in each case is determined by whether the other case has previously reached final adjudication. Which case is adjudicated first inay depend upon inorally arbitrary facts, including crowded court calendars, delaying tactics by opponents, and the like. The outcome, therefore, appears similarly morally arbitrary. As stated earher, ${ }^{129}$ if the three-step case is decided first, plaintiffs win in both the three- and four-step cases. If the four-step case is decided first, both defendants win.

The arbitrariness, however, extends beyond the unfairness to the losing litigants in the three- and four-step cases. The rights of parties hitigating events that occurred after both the three-step and four-step cases also depend upon the order of the three- and four-step cases. While the unfairness to these later litigants is diminished by the notice provided by the earlier decisions, it is not completely eliminated. Adjudication of a series of legal issues in one order gives rise to law that may differ from the law that would exist had the same issues been decided in a different order. Legal rights depend not only upon which prior cases have been decided, but upon the order in which the cases have been decided.

This Article has shifted from the claim that coherence leads to ripple effects and to the linear ordering problem to the claim that the dominant conception of precedent does. ${ }^{130}$ In fact, both claims are true because precedent serves as a principle of conservation in coherence theories of law. ${ }^{131}$ Coherence theories are simply one particularly fa-

128. See supra text accompanying notes 65-67.

129. See supra text following note 66 .

130. This shift occurred even earlier in this Article. See supra text accompanying notes 65-69.

131. The linear ordering problem and the associated ripple effect will occur in conservative 
vored way of spelling out what has here been called the dominant conception of precedent. Because philosophers, including legal philosophers, have lately become enamored with coherence theories, ${ }^{132}$ the ripple effect has been described im terms of coherence so that its connections to other coherence theories are more readily observable. Generalizing beyond coherence theories, we may conclude: the doctrine of precedent requires morally arbitrary decisions, and morally troubling retroactive apphication of law.

coherence theories outside the law. Many, if not most, coherence theories in modern epistemology include conservative principles that lead to the linear ordering problem and ripple effects. In Quine's epistemology, for example, the maxim of minimum inutilation recommends that one's behiefs be readjusted in the face of new information or evidence by changing one's overall nctwork of beliefs as little as possible. W.V.O. QUINE, Two Dogmas of Empiricism, supra note 3, at 44. How new infonnation is evaluated and accommodated depends upon one's prior beliefs. Those beliefs, in turn, depend upon the order in which prior evidence lias been presented. Conservatives generally believe that history inatters, and pragmatists who lold conservative cohcrence theories of evidence and truth are no exception. However, the ripple effect is less surprising, and therefore less troubling to pragmatists: they are likely to embrace the conclusion, given the skeptical tcnor of their theories.

Although nonconservative colierence theories that avoid the ripple effect and the hear ordering problem could be constructed, they would not appeal to these pragmatists. Nonconscrvative colerence theories would require that observations, data, or evidence be detcrmined and characterized independently of prevailing theory. Otherwise, each piece of data would depend upon the theory prevailing wheu the data was acquired, thereby reintroducing the ripple effect and limcar ordering problem. Since pragmatists inaintain that observations are dependent upon prevailing theory, they will reject nonconservative coherence theorics. For example, thesc theorists claim that we perceive a stick in water as straight even though it appears bent because we know something about the consequences of the refractive properties of water and light. See generally Moore, supra note 13, at 1109-10 and the references cited therein.

In one respect, legal data is also dependent on prevailing theory. The issues that are raised by the participants in a lawsuit will depend upon their views of what the law is.

132. See supra notes 3-11. 